\title{
Nuestra historia violeta. Feminismo social y vidas de mujeres en el siglo XX: una revolución permanente, de María Angélica Illanes*
}

(Santiago de Chile: LOM, 2012).

\author{
Gilda Luongo \\ Universidad de Chile \\ gildaluongo@gmail.com
}

"No tan ausente el criterio/ me anuncia muy pequeñital qu' en libertad mi mamital vive en un cruel cautiverio".

Violeta Parra, Décimas, 78.

"a mi modo de ver, no bastaba solamente pensar, ni solamente vivir: yo sólo estimaba sin reserva a la gente que pensaba su vida [...]".

Simone de Beauvoir, Memorias de una joven formal, 226.

En mis manos, el texto-arpi- jeres con nombre propio (mullera-sin final de María Angélica chas de ellas antes no eran vistas Illanes. En este tapiz tejido, bordado y cosido con mano memoriosa, la autora compone lugares de sujetos femeninos creadoresluchadores en el siglo XX en Chile. La investigadora-historiadora parte en busca de sujetos femeninos y sus relatos (imagino que Violeta Parra diría de María Angélica Illanes: "mujer que tiene sentido tranquea con pies de plomo"'). En este tránsito viajero buscador, aparecen muni sabidas) espejean, resuenan, reverberan la hebra cantora-recopiladora-creadora de Violeta. Mujeres de pueblo, de origen humilde, de gran fuerza y tesón para hacerse un espacio en el mundo de la creación-ideación en este país nuestro. Difícil afán. Sujetos de una revuelta múltiple encadenados en puntadas finas, sutiles y otras de hilván, como para seguir enhebrando, encandelillando, para encender una y

* Presentación en Librería Nosotrxs, 16 de noviembre de 2012. 
otra vez las revueltas íntimas y las del lazo social-político (Julia Kristeva).

Bosquejo a continuación los lugares, sitios, espacios que componen y albergan este texto-arpillera-crónica violeta-sin final, porque las historias/ relatos de las mujeres y de los feminismos -afortunadamente- no acabarán nunca.

\section{1}

Violeta Parra. Su vida/escritura/textura en las arpilleras de los sesenta y la escritura autobiográfica de las Décimas asoma como un intertexto tejido con paciencia. Si sólo recorriésemos este trazo fragmentado a partir de los epígrafes en Nuestra historia violeta tendríamos otra historia singular, una más, entre tantas que aparecen en el texto. Escribir en tono de "literatura menor" (Deleuze y Guattari) nos arroja de lleno al espacio autobiográfico. Éste en cruce con el dialogismo bajtiniano (Leonor Arfuch) nos dona una trama nocional amigable para indagar en las dimensiones narrativa y ética de la construcción de subjetividades tramadas memoriosamente en el juego yo/otras (Luongo).

Violeta Parra en las Décimas expone las condiciones de su producción: de escritura y de trabajo. Año 1959: "tanto trabajo", "el bolsillo pobre", "tengo cuatro chiquillos a quienes dar el sustento". Confiesa que toma la guitarra para "repararme los nervios". Su conciencia abierta para decir sobre las dificultades de ser mujer, trabajadora desde lo precario y madre jefa de hogar.

Se asume como caso. Leo lo femenino como percepción compleja, densa y la demanda múltiple de este lugar abismal que necesita llenar: "Hermano sencillo que no comprendís mi caso": "no sabís que un solo lazo lacea un solo novillo". Dificultad para hacer frente a las múltiples tareas que implica llegar a construir la sujeto que ha deseado con afán: devenir artista popular en Chile.

Sin embargo, toma el desafío y lo encauza laboriosa en la recopilación, el canto, los bordados, la escritura y composición de canciones y de las Décimas. Comprende que la escritura calma los tormentos del alma. Emerge el espejo de tinta como una posibilidad de verse y tomar distancia de sí, resuena la petite histoire (Silvia Molloy). La autodesignación y la recuperación de la memoria se transforman en territorio tomado por la sujeto, así, a la 
manera de un abrazo.

\section{2}

La labor de las arpilleristas. Desde la portada, el texto nos asoma a la labor de las mujeres que hilaron, cortaron, seleccionaron telas y tejidos. Violeta también se espejea en este quehacer, fue arpillerista. Sus tapices parecían expandir su labor creadora más allá de la guitarra, de la escritura. En otro contexto epocal, habiendo partido la Viola, las temáticas de las arpilleras creadas por las mujeres en las décadas de los setenta en dictadura, nos narraban de modo sutil composiciones de diverso tono acerca de la resistencia. La lucha de un pueblo que hacía frente a la muerte y al terror. Eran mujeres dadas a las labores de costura para paliar el hambre y junto con ello, testimoniaban su existencia cotidiana, se trataba de vivir para no morir (Marjorie Agosín). El tono de estas arpilleras, sin embargo no era lúgubre, sino colorido y esperanzado como el color de la carne y hueso vivos del texto de María Angélica Illanes.

\section{3}

Trenzar las revistas creadas por las mujeres. Estas produc- ciones ligadas a impulsos libertarios y resistentes posibilitaron tomar la organización, la educación en las propias manos, atisbar la emancipación y porfiar en el camino de la politización. María Angélica Illanes toma un nombre "la mujer" y lo apellida con la revista o medio creado: la mujer alborada, la mujer palanca, la mujer nueva, la paloma en vuelo. Podemos agregar la mujer Furia, revista levantada por Julieta Kirkwood y otras mujeres en los ochenta. Entonces, en aquella década, batallaban las múltiples diferencias de lo femenino, este asomo plural ponía a las lesbianas del Ayuquelén, las de Tel, y a tantas otras mano a mano con las feministas heterosexuales. Las revistas de/para las mujeres en la primera mitad del siglo XX constituyeron el cultivo para poner la palabra pública, la ideación heterogénea, plural prolífica, como (nos)otras, nido para hacer y re-visar la historia, las historias.

\section{4}

La politización. Punto de inflexión de la emancipación de las mujeres. María Angélica Illanes señala con lucidez que no basta con la educación sino que es necesario ir más allá: en- 
caminarse hacia la politización. Este proceso emprendido por las mujeres ha tomado dos cauces: el proyecto político global: militancia en la izquierda de Chile, adherir a su proyecto democrático-revolucionario antes del Golpe y después del Golpe el intento por recuperar la democracia para el pueblo entero; el otro, más sinuoso e irregular: porfiar en la singularidad sexogénero, la rebelión por la vía política feminista: "democracia en el país y en la casa"; "si la mujer no está la democracia no va". Esta última opción política ya sabemos, es de difícil totalización. Se hace de múltiples maneras y pareciera que su propia incubación nos encamina hacia disputas, desacuerdos. El movimiento constante plegado en contradicciones, paradojas, ires y venires; nuevos énfasis y tensiones en cada época y territorio. Las revueltas de ayer iluminan las de hoy; éstas aparecen más múltiples que nunca, las acciones diversas de las compañeras y compañeros feministas lésbic@s, trans, queer, terroristas del género, postfeministas parecieran habernos arrastrado a un punto de inflexión máxima en este sentido; uno que resiste inclusive la articulación y el juego fantasioso de un solo conglomerado, desafío ético-político que nos compele a la apertura de la imaginación.

\section{5}

Un tapiz compuesto de políticas del nombre propio: "el feminismo soy yo". Como Julieta afirmara: "en el sentido más humanamente cierto quisiera decir el feminismo soy yo". Constatación de la diversidad y la multiplicidad en su apertura singular, incubación de vías político-feministas, amasijo y cultivo posibles. Los más de cien nombres de mujeres que aparecen en el texto sosteniendo en sus cuerpos testimoniantes las huellas de una historia violeta parecen decirnos: el feminismo soy yo/ nosotras.

“Ya está corrido el telón". 